THE MENTAL HEALTH IMPACTS OF IMMIGRATION DETENTION CENTERS ON ASYLUM SEEKERS:

A COMPARATIVE ANALYSIS OF CANADA AND THE UNITED STATES

by

\begin{abstract}
Abid Hashimi
Bachelor of Arts (Honours), University of Toronto, 2017

A Major Research Paper

presented to Ryerson University

in partial fulfillment of the requirements for the degree of

Master of Arts

In the program of

Immigration and Settlement Studies
\end{abstract}

Toronto, Ontario, Canada, 2020

(C) Abid Hashimi 2020 


\section{AUTHOR'S DECLARATION FOR ELECTRONIC SUBMISSION OF A MAJOR RESEARCH PAPER (MRP)}

I hereby declare that I am the sole author of this Major Research Paper. This is a true copy of the MRP, including any required final revisions, as accepted by my examiners.

I authorize Ryerson University to lend this MRP to other institutions or individuals for the purpose of scholarly research.

I further authorize Ryerson University to reproduce this MRP by photocopying or by other means, in total or in part, at the request of other institutions or individuals for the purpose of scholarly research.

I understand that my MRP may be made electronically available to the public.

Abid Hashimi 


\title{
THE MENTAL HEALTH IMPACTS OF IMMIGRATION DETENTION CENTERS ON ASYLUM SEEKERS: A COMPARATIVE ANALYSIS OF CANADA AND THE UNITED STATES
}

\author{
Abid Hashimi \\ Master of Arts, 2020 \\ Immigration and Settlement Studies \\ Ryerson University
}

\begin{abstract}
This paper is a literature review examining the mental health impacts that immigration detention centers have on asylum seekers in Canada and the United States (US). Drawing evidence from the social exclusion framework, it assesses explicitly the negative connotation of being isolated from society. The review focuses on the inability of detention centers in dealing with asylum seekers with pre-existing mental health conditions; how inadequate access to proper health care contributes to extending their existing mental health concerns; and how detention centers resemble forced confinement and contribute to family separation adding to the trauma of detainees, specifically children. In addition, this paper recommends that Canada and the US must adopt Alternatives to Detention (ATD) with a specific focus on Community Based Programs as policy adjustments to deal with asylum seekers effectively.
\end{abstract}

Key words: Asylum seeker, Refugee, Immigration Detention Centers, Law, Policy, Mental Health, Depression, Anxiety, Post-Traumatic Stress Disorder (PTSD), and Deportation. 


\section{ACKNOWLEDGMENTS}

I would like to acknowledge the dedication and guidance of my supervisor, Dr. John Isbister. I am very grateful for the continuous guidance, supervision and constructive feedback that helped me to complete my MRP.

I would also like to thank Dr. Mustafa Koc as my second reader for providing his time, guidance, editing recommendations, feedback, and encouragement to complete my MRP.

I would like to thank my parents for their unconditional love and support throughout my master's degree, without their support and contributions, I would not have been able to complete this paper.

Finally, I would like to thank Rafia Khalil, who has played a very supportive role as a mother, friend, colleague, and a mentor. She played a pivotal role in my MRP and overall encouraging me to work hard and not give up. Thank you so much. 


\section{LIST OF ABBREVIATIONS}

ATDs

CBSA

DHS

FCMP

ICE

IHC

IRPA

ISS

ICDI

RCPM

PTSD

USA

US

UDHR

UNHCR

UN
Alternative to Detentions

Canadian Border Services Agency

Department of Homeland Security

Family Case Management Program

Immigration and Customs Enforcement

Immigration Holding Cell

Immigration Refugee Protection Act

Immigration and Settlement Studies

Interfaith Community for Detained Immigrants

Royal Canadian Mounted Police

Post-Traumatic Stress Disorder

United States of America

United States

Universal Declaration of Human Rights

United Nations High Commissioner for Refugees

United Nations 


\section{TABLE OF CONTENTS}

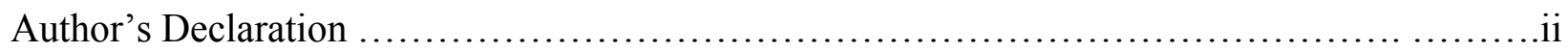

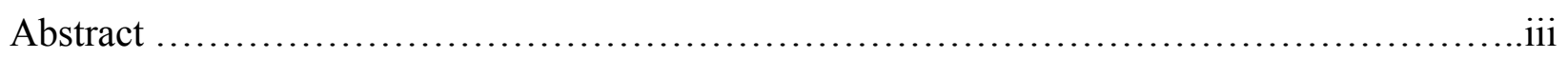

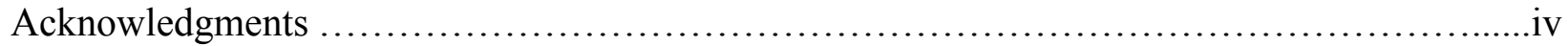

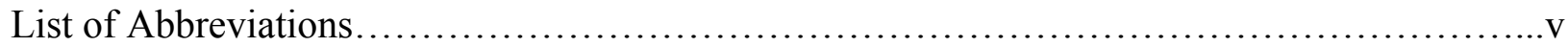

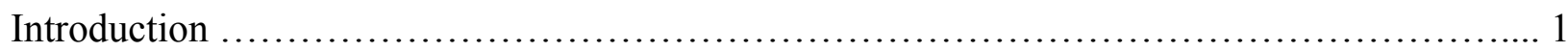

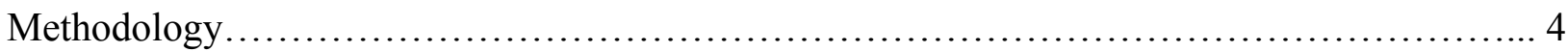

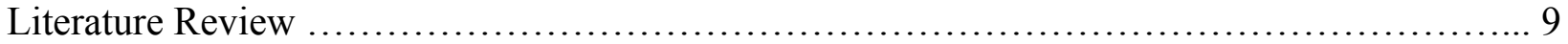

- Canadian and United States Immigration Law \& Policies .............................. 9

- The Nature of Immigration Detention Locations in Canada \& the US....................12

- Range of Mental Health Implications for Asylum Seekers in Detention Centers........... 17

○ Consequences of Staying in Detention Centers.............................. 18

○ Inadequate Access to Health Care in Detention Centers..........................23

- Implications Resulting from Limited Access to Health Care ..................... 25

- Resemblance to Force Confinement Imposing Family Separation........................ 31

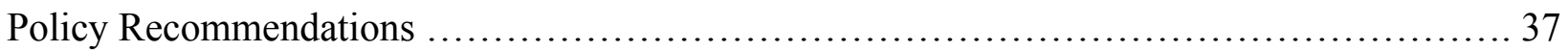

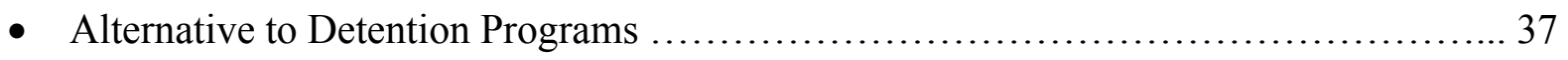

- ATD Community Based Programs ................................................. 39

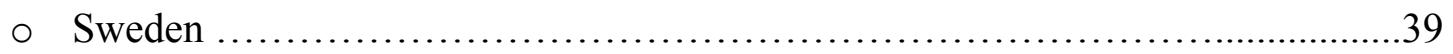

○ The Toronto Bail Program...................................................... 40

$\circ \quad$ Marie Joseph House ............................................................ 42

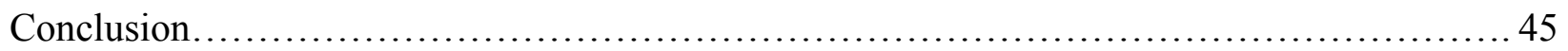

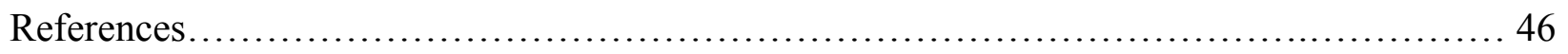




\section{INTRODUCTION}

Due to the ongoing situations in many countries around the world, specifically Syria, Iraq, and the Central American nations of Guatemala, Honduras and El Salvador, a large number of individuals and families have been leaving their homes in search for safety in countries where they feel they have a better chance at living a normal life. According to the UN Refugee Agency (UNHCR), by the end of 2018, there were over 70 million individuals who, as a result of either conflict, persecution, violence, or human rights violations in their native country, were forced to become displaced and seek refuge elsewhere. ("Refugee Statistics | USA for UNHCR," 2020). Further statistics show that 3.5 million of the 70 million have become asylum seekers in western countries, which offer a safe haven for these traumatized individuals and families ("Refugee Statistics | USA for UNHCR", 2020). It is reported that Canada has resettled more refugees than any other country with the United States (US) coming in second (Berlinger, 2019). Thus, both Canada and the US have played pivotal roles in responding to the crisis of refugees from different parts of the world and have acted as global leaders for the accommodations and resettlement of refugees who have been displaced from their home countries for varying reasons (American Immigration Council, 2019; Saberpor, 2016). Canada specifically has projected itself as a progressive country on the global stage for accepting immigrants, primarily refugees and asylum seekers, and by protecting and respecting their fundamental human rights (Saberpor, 2016). According to the UN report, Canada took in 28,100 and the US took in 22,900 refugees in 2018 (Berlinger, 2019).

It is evident from these numbers that Canada has maintained a long history of responding to various refugee crises by accepting and accommodating refugees from different parts of the world at varying times (Lacroix, 2004). In the early 20th century, Canadian immigration policies 
were strict in terms of welcoming and accepting refugees; however, they did not fully restrict refugees from migrating to Canada completely. Post-war humanitarianism played an essential role in Canada, bringing close to a quarter of a million refugees and displaced persons between 1946 and 1962 due to war, violence, and persecution (Epp, 2017). Thus, post-war humanitarianism contributed to the evolution of Canadian immigration policies, becoming more lenient to respond to the refugee crisis. Over the course of time, more refugees were welcomed and accepted in Canada without facing harsh restrictions (Epp, 2017).

In contrast, the US also has maintained its own strong history of accepting and resettling a large number of refugees (American Immigration Council, 2019). For instance, a report published by the UN refugee agency UNHCR documented that a significant number of asylum seekers come to the US from El Salvador, Guatemala, Honduras, Mexico, and Panama (Musalo and Lee, 2017). Addressing the issues of irregular arrivals without sufficient documentation can cause many problems for immigration enforcement officers; therefore, Canada and the US have resorted to relying on immigration detention facilities in order to house asylum seekers (Musalo and Lee, 2017; Muscati, 2018). Furthermore, it became evident during this literature review, that due to the fact that Canada and the US receive a large number of refugees and asylum seekers, they had to implement and tailor their own style of immigration laws and policies to administer immigration detention centers to hold asylum seekers (Musalo and Lee, 2017; Muscati, 2018).

This paper, therefore, extends the insufficient literature pertaining to immigration detention policies which have been curated to detain asylum seekers in Canada and the US (Alamyar, 2016; Musalo and Lee, 2017; Muscati, 2018). More specifically, this paper's focus is on examining the mental health issues faced by asylum seekers in immigration detention centers. It poses the following research question: What are the mental health impacts of immigration 
detention centers on asylum seekers in Canada and the US? Judging from a social exclusion theoretical framework, this paper will attempt to analyze the consequences of immigration detention centers on the mental health of asylum seekers in Canada and the US. The central argument of this paper is that immigration detention centers impose crucial mental health outcomes for asylum seekers that are detained, especially families and children. It is argued that detention centers worsen mental health problems such as post-traumatic stress disorder and high levels of anxiety that refugees may already suffer from. Secondly, inadequate access to proper health care in detention centers further worsens the pre-existing mental health concerns of the asylum seekers. Thirdly, the living conditions in these detention centers which resemble forced confinement create family separation that can result in trauma for all family members, especially the children. To achieve this end, through an in-depth review of the literature, this paper will first look at the immigration policies of Canada and the US in order to have a precise examination of how asylum seekers are treated. Second, assess the conditions of detention centers in both countries and the type of asylum seekers contained in these facilities by mainly focusing on the location and the physical state of the detention centers, as well as who the detainees are and examine how they are treated. Third, this paper will examine in depth the wide-ranging implications of mental health problems for asylum seekers in the detention centers. Finally, this paper will extract from the literature review, policy recommendations to policymakers which provide better alternatives than detention centers. 


\section{METHODOLOGY}

This paper is an exploratory attempt to examine the impacts of detention centers on the mental health of asylum seekers in Canada and the US. While initially, the intention was to conduct interviews with asylum seekers who had stayed in these detention centers and some human rights lawyers, given research ethics concerns and shortage of time, it was decided to limit the research to a comparative review of literature on detention policies for asylum seekers and the mental health consequences resulting from the isolation of the aforementioned asylumseeking detainees who were confined to remain in detention centers in Canada and the US while they awaited decision on their refugee case. For the literature review, an in-depth examination of scholarly articles, policy documents, and the popular press was conducted to gather data for this paper. Academic articles, social science, and medical sources were analyzed in order to extract information on detention centers and the negative impacts it has on asylum seeking detainees. Furthermore, the assessment of medical articles provided a thorough overview of the mental health situation of detainees in detention centers.

Moreover, research for this paper was conducted through Google Scholar, Social Science Index, Ryerson Article and Databases, and the University of Toronto Databases, which provided access to very resourceful links and articles. The Ryerson and University of Toronto databases were the most useful in terms of accessing academic sources, which couldn't be accessed through Google Scholar because of the prohibition that stipulates that only the educational institutions that have an agreement with different partners are given full access to scholarly articles and links, which are then made available to students for access. 
While conducting the research, specific keywords were used to gain access to the required information that guided the research, which included the following: asylum seekers, refugees, detention centers, immigration law, policies, mental health, depression, anxiety, PTSD, and family separation. These words narrowed the research focus and generated the results that were needed to use for the literature review. The Ryerson Article and Databases provided the options of further narrowing the research focus by using keywords, which was very beneficial in the overall research. In addition, the inclusion and exclusion criteria were used to narrow the attention of the study and find data that was relevant to the research topic.

The focus of the research for this MRP was limited on purpose to only Canada and the US because of the similarities in the law, policies, and procedures that are used in addressing the issue of asylum seekers and/or people without legal documentation. Both nations have strongly relied on the detention center as a long-term solution in dealing with asylum seekers and refugee claimants. It was imperative to conduct a study on the negative psychological impacts of detention centers on detainees. There is scholarly data available that acknowledges detention centers and briefly documents the mental health issues that detainees suffer from. However, there was insufficient literature available that mainly focused on Canada and the US. At the same time, there are collaborative studies done on the topic mentioned above in countries like Australia, New-Zealand, the United Kingdom, which included Canada and the US. Therefore, it was decided that additional research was needed, which should primarily focus on Canada and the US. In addition, this paper contains scholarly information that is very recent, which dates from 2010 to 2019 and contributes to the existing literature. The literature review on the aforementioned topic has to be always updated because the arena of immigration law and policies is always changing and evolving. Therefore, the information provided in this literature 
review sheds light on immigration detention center policies in Canada and the US, through gathering information from updated individual studies and reports, to illustrate the changes that have been implemented. In-Depth research like this with recent data has not been produced that explicitly focuses on Canada and the US, and thus, this literature review fulfills the purpose of providing current data.

In this paper, the social exclusion framework will be used to conceptualize the manufacturing of exclusion(s) of asylum seekers in detention centers across Canada and the US. The concept of social exclusion is a framework that is multidimensional since it is used in fields such as sociology, human geography, and political science to understand the lives of individuals and communities that are excluded from participating in the economic, social and political fabric of the society (Levitas et al., 2007). Thus, Levitas et al. (2007) have defined social exclusion as a process that is "complex and multidimensional and it involves the lack of denial of resources, rights, goods and services, and the inability to participate in the normal relationships and activities, available to the majority of people in a society, whether in economic, social, cultural or political arenas. It affects both the quality of life of individuals and the equity and cohesion of society as a whole". Richmond (2002) extends this point by arguing that social exclusion takes place where individuals are socially excluded from having similar opportunities in societymostly due to discrimination based on nationality, language and religion.

The aforementioned social exclusion framework is furthered assessed by Janet Taylor, who conducted a literature review called Refugees and Social Excision (2004). This literature review mostly focuses on refugees, including asylum seekers and undocumented individuals in Australia, in terms of the rise of poverty among the refugee population due to social exclusion (Taylor, 2004). 
Taylor (2004) has shown how different aspects of social exclusion, such as being lowincome, unemployed, on income support, having limited or no access to health care and education, all contribute to the poverty of asylum seekers. Furthermore, all of these factors can be used to describe how asylum seekers and refugees can experience discrimination through social exclusion. The review further assesses that the most significant aspect of social exclusion that asylum seekers encounter in Australia is the physical exclusion of being removed from the country by being detained for a lengthy period in detention centers located in remote areas (Taylor, 2004).

Thus Taylor (2004) has articulated that this physical removal of the asylum seekers and refugees from Australian society has caused severe mental health impacts resulting from this form forced social exclusion. The physical detainment of asylum seekers and refugees is preventing them from having access to similar opportunities and resources as the rest of Australian society (Taylor, 2004).

A reference can be drawn from the Australian case study by analyzing the Canadian and the US context with respect to detention centers and social exclusion. These two nations are actively benefiting from immigration detention policies to cater to the high class and deter unwanted migrants that would become a burden on the welfare systems (Musalo and Lee, 2017; Muscati, 2018). For instance, geographically detention facilities are socially excluded and marginalized to prevent refugee families and children from moving freely and from connecting with the general public or any relatives they may live in the host country which is a violation of their Universal Declaration of Human Rights (UDHR) (Martin, 2015). Article 13 of UDHR promotes that everyone has the right to freedom of movement to remain within the borders of each state and can leave anytime without any compulsion (UNHCR, 2015). However, detention 
centers have taken these rights away from the detainees by subjecting and confining them to detention centers and segregating them from their family members. The violation of their human rights can be further explained and supported by Richmond (2002) that social exclusion is not only about poverty or having access to similar resources. Rather social exclusion extends beyond that, which is violating and taking away their human rights enshrined in the UDHR.

The aforementioned methodology of examining how detention centers in Canada and the US have detrimental effects on the mental health of asylum seekers is important to the Immigration and Settlement Studies (ISS). ISS is an innovative and multidisciplinary program that offers students the opportunity to explore immigration trends and policies from a unique lens by providing them with the tools and resources. Immigration law and policies are an arena that is always changing and evolving in Canada and the US. There is a high volume of information available, highlighting the importance of detention centers and the mental health implications associated with it. However, to have comparative analysis available that documents the mental health impact of detention centers on asylum seekers in Canada and the US is a significant contribution to the ISS program, which eventually paves a path for other students to expand on this topic and present new research questions that can be a further addition. Overall, this research topic fulfills the mandate of the ISS program. 


\section{LITERATURE REVIEW}

\section{Canadian and US Law \& Immigration Policies}

This section of the paper focuses on examining the various law, policies, and procedures dealing with asylum seekers in Canada and the US, which are used to determine the eligibility of asylum seekers at the port of entry until their immigration hearing to determine their status. It is evident that when it comes to immigration law and policies, there are similarities between both countries. For instance, Canada and the US have both implemented similar immigration policies and procedures that have been developed to determine if an applicant would be admissible or inadmissible to make an asylum claim. In order to fully grasp the context of these policies and procedures followed by both Canada and the US, one must understand the definition of asylum seekers and how immigration laws are tailored to permit asylum seekers to make a claim in these two countries. The definition of asylum seeker differs from country to country. For instance, according to the United Nations (UN), an asylum seeker is defined as someone who moves across borders for seeking personal and political refuge and is waiting for their status to be determined by the nation-state they are in. Similarly, asylum seekers may become refugees once refuge has been granted by the state (Wood, 2018).

Canada currently follows the Immigration and Refugee Protection Act (IRPA), formerly known as the Immigration Act, 1976, that permits individuals to apply for entry and migrate to Canada. According to the definition of a Convention refugee, Canada has introduced a category for refugees that are escaping persecution, war, and violence. It is granted protection based on humanitarian and compassionate grounds (Quigley, 2013). The rules and regulations outlined in IRPA are used to assess every individual seeking to enter Canada. In addition to the IRPA, Canadian Border Services Agency (CBSA) and the Royal Canadian Mounted Police (RCMP) 
play a crucial role in protecting Canadian borders and the general public in ensuring that individuals entering the country are not only admissible but also irregular entries are prevented (Government of Canada, 2019; Quigley, 2013). For instance, the RCMP is responsible for protecting the border security between the port of entry by working with domestic and international partners to prevent irregular entries. At the same time, the CBSA is there to protect border security at both the port of entry and inland offices (Government of Canada, 2019).

The undocumented individuals that come to the port of entry to enter or make a refugee claim in Canada are immediately detained and taken to immigration detention centers. To adequately comprehend the purpose of immigration detention centers in Canada, it is necessary to analyze the Canadian legislative framework (Molnar, 2017). The Canadian Immigration detention centers fall under the framework of Administrative law, illustrating that an individual who gets detained by the CBSA has not by any means committed a crime by breaking any Canadian law under Canada's Criminal Code (Molnar, 2017). Instead, individuals are held in the detention centers for immigration reasons, until each person is cleared to be admitted into Canada. IRPA has further authorized the CBSA to detain a person without proper documentation or if there are any posed threats to the public or national security (Molnar, 2017).

A similar approach is implemented by the US with respect to the treatment of undocumented migrants, which includes all Canada-US and Mexico-US port of entry locations. At the port of entry, the individual must present valid documents such as a passport as part of the entry process (USA.Gov, 2019). Individuals with valid documents and visas are permitted to enter the US while individuals without valid documents may be deported immediately without an immigration court hearing, while others may appear before a judge to determine whether they should be deported or permitted to remain in the country (USA.Gov, 2019). With respect to 
dealing with refugee claimants, under the US law, a refugee is defined as someone unable or unwilling to return to their source country because of a well-founded fear of persecution to their religion, national origin, sexual orientation, and political opinions or activities (USA.Gov, 2019). This definition meets the requirement of the convention refugee outlined by the United Nations 1951 Convention and 1967 Protocols (American Immigration Council, 2019).

The US has played an essential role in the acceptance and resettlement of refugees, who are fleeing their source country for whatever reason and has allowed them to re-settle in the US. However, for the US to address the crisis of refugees and asylum seekers, the identity and status must be determined to meet the definition of a conventional refugee (American Immigration Council, 2019). On an annual basis, a large number of refugees and asylum seekers are crossing the borders from Central America, Europe, and the Middle East due to persecution, violence, and war in search of safety in the United States (Teicher, 2018). To address the issue of the mass number of refugees and asylum seekers entering the US, individuals without proper documentation are detained for unlawful entry, and their claims for asylum are received (USA.Gov, 2019). Asylum claimants are then placed in detention centers until either they are released into the US by parole or the process of their deportation and removal from the country is completed (USA.Gov, 2019).

Governments of different nations around the world have been relying on immigration detention policies to control irregular immigration population. Immigration detention policy has been strongly preferred by various states to maintain their authority and legitimacy as well as respond to the growing concerns of border security as a result of the refugee crisis (Sampson and Mitchell 2013). Canada and the US are two nations that have adopted immigration detention policies to control irregular migration and maintain the status quo. This practice, however, has 
had severe impacts on the mental health of asylum seekers that are held in these detention centers. (Muscati, 2018; Sampson and Mitchell 2013).

It is evident from the above literature review that there are similarities between Canada and the US in terms of their immigration policies, procedures, and protocols in addressing the issues of refugee claimants and asylum seekers. In addition, the literature review has provided reasons as to why these countries rely on immigration detention facilities when dealing with individuals without valid documents.

\section{The Nature of Immigration Detention Locations in Canada \& the US}

The location of these detention facilities both in Canada and the US are typically hidden from urban areas to off-shore areas. Historically, exact figures of detained migrants and specific policy directions governing immigration detention are difficult to ascertain in Canada, but in the last two decades, there is overwhelming evidence highlighting the detainment of refugees and asylum seekers have increased (Molnar, 2017). In Canada, three detention centers are regulated by CBSA and are fully operational Immigration Holding Cells (IHCs), which are located in Toronto, Montréal, and Vancouver. For instance, the first detention facility is the Toronto Immigration Holding Centre (TIHC), which opened in 2004 and has served as the primary detention facility; second facility is the Laval Immigration Holding Centre (LIHC) located in Montreal that can hold up to 150 detainees; the third facility is the B.C. Immigration Holding Centre (BCIHC) located in Vancouver (Global Detention Project, 2017).

Canada has been relying on these three facilities for the last two decades to hold undocumented detainees. However, over time, the use of provincial jails and prisons for immigration detention purposes has steadily increased throughout Canada. Canada has been strongly relying on these facilities to detain and deter asylum seekers from occupying urban 
spaces (Martin 2015; Muscati, 2018). The literature review strongly suggests that the detainment of asylum seekers and refugee claimants does not only violate their human rights, it also limits their liberty as they are also subjected to deplorable conditions in the detention centers (Muscati, 2018).

In contrast, research has shown that in the US, more than tens of thousands of asylum seekers are held in detention centers by the government. Many of these detention centers are controlled and operated by Customs and Border Protection (CBP), mostly the Border Patrol and the Immigration and Customs Enforcement (ICE) (US Immigration and Customs Enforcement, 2018). Asylum seekers are detained for not having valid documents when entering the US, before their immigration hearings, during the stage of determining their status. For instance, in 2018, almost 400,000 were held in American detention centers, and this number continues to increase on an annual basis. Studies have shown that 242,778 were detained by CBP and 153,670 by ICE. More specifically, this included a daily average of 42,188 immigrations (40,075 adults and 2,113 in families) being detained by ICE 2018 (US Immigration and Customs Enforcement ,2019). It also reported that thousands of children are detained by different facilities that are operated by the Refugee Resettlement's Program for Unaccompanied Alien Children (Lind, 2019). And the children continue to suffer the most in these facilities because of their age and vulnerability, making them more prone to further developing mental health issues (Lind, 2019). The above statistics speak volumes of how strongly the US is relying on immigration detention centers, and as a result, immigrant detainees are suffering the most.

Assessing the history of immigration detention centers in the US can be traced back to Ellis Island in the 1890s, which was used as a permanent holding place for foreign nationals during WW2 and up until the 1950s (Goldman, 2016). During the 1980s, a large number of 
asylum seekers began arriving in boats from Haiti, forcing the then US President, Ronald Reagan, to react and send them to detention centers as a means to deter the mass migration (Ghosh, 2016). As the number of undocumented immigrants that were fleeing economic and political conditions increased, President Bush Sr. resorted to a regional location to address the issue of the massive influx of undocumented Haitians (Wasem, 2010). The UNHCR tried to work out a deal with Belize, Honduras, Trinidad, and Tobago, and Venezuela to assist Haitian refugees for a temporary period until the best solution was reached, but the coast guard was overwhelmed by a large number of Haitian refugees in 1991, resulting in 538 Haitians being returned to Haiti (Wasem, 2010). However, deporting refugee claimants to their source country proved to be an inadequate approach that jeopardized their lives and safety, and a focus was once again brought towards developing better immigration policies (Wasem, 2010). This, in brief, is the early history of the development of immigration detention in the US.

Since the development of immigration detention centers in the US, the size and cost of these detention centers have increased and grown. The removal operation has also increased since the 1990s, making it difficult for the US to tackle the issue of irregular arrivals (Global Detention Project, 2017). It is further highlighted that the overall number of detainees annually increased from 85,000 in 1995 to almost 478,000 in the fiscal year of 2012 (Global Detention Project, 2017).

Addressing the growing number of detainees in the US detention centers, the Obama Administration in 2009 introduced policies to reform the detention centers to reduce the number of people being detained. The reforms did reduce the number of detainees, but overall it was not effective. From 2009 to 2012, the number of detainees increased, and the government could no longer provide any long term solutions to address the increasing number of detainees. In 
addition, the country also deported a large number of non-citizens, increasing the total number to 438,421 during the 2013 fiscal year (Global Detention Project, 2017).

The above-outlined situation of immigration detention centers in the US speaks volumes, and the literature further assesses that as the number of asylum seekers increased, the government relies more and more on detention centers. Today, across all 52 states in the US, the detention centers are utilized to hold asylum seekers until their immigration hearings or deportation (Global Detention Project, 2017).

In Canada, the purpose of immigration detention centers is to hold individuals that are migrating to Canada to make refugee claims or seek asylum by making sure that they go through the due process without any unfair treatment or violation of their fundamental human rights (Atak and Hudson, 2012). Once a decision has been made regarding their status, the migrant is either allowed to make a claim or is safely deported back to his/her country (Molnar, 2017). However, the literature review has pointed out that Canada has turned refugees, asylum seekers, and undocumented migrants into criminals, holding them in detention centers for lengthy periods without any criminal charges. In most cases, the conditions and treatment of the individuals are inhumane and a violation of their fundamental human rights (Muscati, 2018). The process has contributed to the criminalization of refugees, asylum seekers, and undocumented migrants, which can have adverse long-term effects on these individuals, primarily children (Muscati, 2018).

This literature increasingly highlights the nature of detention centers and their impact on the mental health of detainees in Canada. There are similar policies enacted by the US that govern detention centers in the same manner with respect to the treatment of detainees. The US goes one step further in adopting harsh detention policies to deter a large number of unauthorized 
migrants entering the US to apply for asylum or refugee status (Sampson and Mitchell 2013). As outlined in the early part of the literature that many asylum seekers and refugees entering the US are women with their children, girls and boys, single adults, and entire families who have been fleeing from El Salvador, Guatemala, and Honduras to escape an epidemic of violence that has taken hold of their countries in the past several years (Keller et al. 2017).

In addition, Noferi (2017) has argued that these detention facilities are highly criticized in the US for the deplorable living conditions that detainees are subjected to. There have been numerous recommendations made to improve the overall conditions of the detention centers, however, they have been largely ignored, thus resulting in an increase in the deplorable conditions affecting detainees (Noferi, 2017). Not only do these conditions affect the mental health of immigrant detainees but just the overall impact of being detained for an extended period has resulted in severe mental health implications (Keller et al, 2017).

In short, this literature review demonstrated that for many years the detention centers had been used as camps that house asylum seekers. The placement of these people in these facilities has resulted in restrictions of their freedoms. The governments of both Canada and the US have been able to do this for many years by hiding the locations of these centers from their citizens. The growing scholarship in this arena consistently documents the notion that the way these individuals are treated and where these centers are physically located is impacting the mental health of asylum seekers. Most importantly, the review directed towards investigating exactly how the mere presence and conditions of the sites manufacture mental health implications for asylum seekers in these two nations, and thus the results are cited in this paper. 


\section{Range of Mental Health Concerns for Asylum Seekers in Detention Centers}

There is extensive evidence suggesting that refugees are far more vulnerable to mental health problems, specifically PTSD and high levels of anxiety which leads to depression (Cleveland and Rosseau, 2013). The academic literature shows that pre and post-migration factors play an essential role in the overall mental health of refugees. Pre-migration factors include exposure to violence, torture, war, and human trafficking that results in refugees developing mental health issues such as PTSD, anxiety, and depression. Mitchell (2015) describes the experiences of refugees when fleeing the country and residing in refugee camps with the hopes of safely getting to other countries. He examines how, during this escape, they become more vulnerable to so many unpredictable threats. Wilson et al. (2009) points out that these refugees, including children who are stateless and residing in camps, are given a lack of opportunities, have limited rights, almost always face discrimination, and are often abused. The negative experiences described by refugees in the camps are part of the pre-migration experiences that have traumatized many people resulting in mental health issues. This point is further supported by Von Werthern et al. (2018) that pre-migration experiences remain and affect individuals for a lengthy period. Particularly, refugees, asylum seekers, and undocumented migrants who have previous experiences of war, violence, torture, and persecution have developed post-traumatic stress disorder (PTSD), depression, and anxiety. (Cleveland and Rousseau, 2013). When exposed to the circumstances in the detention centers, they are even more vulnerable to developing further mental health illnesses.

The CBSA in Canada has taken significant steps to implement changes in its immigration detention policies with regards to addressing systemic issues and barriers faced by individuals held in the immigration detention centers (Silove, 2000). However, despite the positive changes, 
detainees continue to suffer from the inhumane and cruel treatments leading to human rights violations (Muscati, 2018). Canada does not provide the maximum period for how long a detainee will be detained in a detention facility, and thus, the Canadian state can detain these asylum seekers for many years (Global Detention Project, 2018).

In contrast, pertaining to the post-migration factors, Ungar (2017) suggested that asylum seekers are already affected by pre-migration factors, as discussed above. However, postmigration factors from their native country to the host country determine their overall mental health issues and real-life experiences. In this case, post-migration factors are the center of the focus in shaping the outcome of the mental health and experiences of asylum seekers (Ungar, 2017). In addition, scholars suggest that post-migration experiences should be positive for refugees that have mental health issues. This can be achieved by equipping them with resources and opportunities to seek refuge and continue to live a good healthy life. Furthermore, Werthern et al. (2018) concluded that when refugee claimants enter a new country, most of them end up in an immigration detention center, which is detrimental to their overall health. An asylum seeker

that spends time in an immigration detention center in the host country is a victim in particular of post-migration stressors that entails the loss of liberty and the threat of a forced return to their country of origin (Coffey et al., 2013).

\section{Consequences of Staying in Detention Centers}

As mentioned earlier, the central argument of this paper is that immigration detention centers impose crucial mental health outcomes for asylum seekers. Of the three arguments put forth in the introduction, the first one examines how detention centers impose mental health issues, such as post-traumatic stress disorder and high levels of anxiety. Although, Canada has been portrayed as a progressive humanitarian country for accepting and aiding asylum seekers 
from all over the world; the literature review points out that it has immensely failed to live up to its expectations and projected image due to the horrible treatment and deplorable conditions in detention centers the refugees are subjected to (Global Detention Project, 2017).

For instance, according to the Global Detention Project (2017), which demonstrated that despite the introduction of a "National Immigration Detention Framework" in 2017— that aims to improve detention conditions and reduce the use of prisons - Canada continues to confine approximately one-third of its asylum seekers in prison-like detention centers. This has been the driving force for mental health conditions such as PTSD and high levels of anxiety, leading to depression. In addition, these mental health issues are exaggerated even further when asylum seekers and refugee claimants are detained for a lengthy period of time (Global Detention Project, 2017).

This paper finds that pre and post-migration factors play an essential role in the long-term psychological effects of asylum seekers. It is evident from the literature review that long-term psychological effects can continue to last for extended periods, long after their release, especially for women and children who tend to be the most vulnerable (Coffey et al. 2010). The contemporary statistics illustrate that since 2013 , more than 800 children were held in various Canadian immigration detention centers (Muscati, 2018). It is found that children who are separated from their parents are subjected to the same treatment as adults. Mothers and children who are separated from their husbands and fathers are then placed in immigration detention centers with strict regulations and routines that limit visitations, walking, and conversing with others (Muscati, 2018). They are also subjected to strict surveillance by guards and security cameras, similar to the treatment of their adult counterparts (Muscati, 2018). 
Similarly, recreational activities and access to the outdoors are limited for children, extending their confinement to the walls of the holding centers. These factors remove children from a healthy environment and place them in a hostile environment instead. This shows that the way children are currently accommodated is not positive for their mental health and results in many of the children in detention centers suffering the most because they cannot have their best interests considered by the adjudicator during a detention review hearing (Cleveland and Rousseau, 2012). This is a clear violation of children's rights, and concerns have been raised by the UN not to have children held in immigration detention centers. However, Canada has continuously violated this international law by detaining children in immigration detention centers. This type of detainment has crucial mental health implications for children as studies have found that detained children have experienced psychiatric symptoms, depression, anxiety, and self-harm, impeaching their overall growth and development (Cleveland and Rousseau, 2012).

The current Canadian immigration policies and practices are clearly in violation of international law and norms. In 1969, Canada signed the 1951 Convention and Protocol to offer more support and respond to the refugee crisis during an emergency. Since then, Canada has become recognized on a global scale as a leader in welcoming and accommodating refugees from all over the world. The leading example can be seen when Canada responded to the Syrian refugee crisis, which crippled Syria with hundreds of thousands of deaths and left more than a million people internally displaced (Epp, 2017). Canada in 2016 accepted more than 40,000 Syrian refugees who were resettled in different provinces of the country, and by the end of the year, that number had reached almost 50,000 (Berlinger, 2019; Saberpor, 2016). 
This response indeed demonstrates that Canada is certainly recognized in the world for its humanitarian approach to the refugee crisis (Epp, 2017). However, despite Canada allowing entry of asylum seekers from different parts of the world, it continues to violate human rights on how individuals should be treated according to the UN. The 1951 Convention states that nations must grant certain individual rights to asylum seekers (UNHCR, 2012). Yet Canada continues to ignore these individual freedoms and rights by continuously placing asylum seekers in immigration detention centers. The progressive Canadian image that has been projected in the global stage does not capture the horrible treatment of asylum-seeking children in immigration detention centers. Canada has turned a blind eye to the UN-led recommendations on how to properly treat refugee claimants that are children. It is imperative to note that when asylum seekers, whether adults or children, are placed in confined detention centers, their fundamental individual rights are stripped for the length of time that they remain in confinement leading to PTSD and higher levels of anxiety (Malina, 2019).

In contrast, when examining the American system, upon arrival at the port of entry, asylum seekers are questioned by immigration officials to determine if they are authorized to enter the country, and any unauthorized or undocumented migrants are taken to immigration detention facilities. Keller et al (2017) points that the growing number of families being detained in detention centers all over the US has resulted in prolonged detention that contributes to the risk of PTSD, depression and leading to higher levels of anxiety. This confinement is not limited to PTSD, depression, or anxiety, as there is evidence that relates to other mental health concerns in the detainee population (Malina, 2019).

The overall mental health issues of immigrant detainees are further extended because of the deplorable conditions of detention centers across the US. For instance, Ellmann (2019) 
describes the conditions of confinement in the detention centers as merely disgraceful. This is because the detention centers do not have proper beds, lack of adequate toilets, no bathing facilities, constant light exposure, confiscation of belongings, insufficient food and water, and there is a lack of access to legal counsel for the detainees (Ellmann, 2019). Also, there have been instances where children and families are even denied the basic medical care and attention (Piwowarczyk, 2007).

Furthermore, according to a study published by the American Immigration Lawyers Association (AILA), it was found that the delays in detention centers and court hearing can take up to four years, which has a negative impact on asylum seekers and their case over time by the loss of evidence and witnesses. While awaiting trial for their status to be determined, it was reported that detainees from Mexico, El Salvador, Guatemala, and Honduras experience great difficulty moving past their trauma and negative experiences that they encountered while escaping war, violence, torture, and persecution (Piwowarczyk, 2007). The delays, coupled with their past exposure, can contribute to further triggering of their mental health issues, including PTSD and high levels of anxiety (Piwowarczyk, 2007).

In most cases, in the detention facilities in the US, it is the children that tend to suffer the most because they are separated from their parents and are detained in separate facilities. In some cases, children are permitted to remain with their mothers in detention facilities, but not with their fathers. This study finds that children specifically are more vulnerable due to their young age and therefore are at a higher risk for greater traumatization, depression, and anxiety as a result of the unpredictable environment found in the immigration detention centers (Hadfield, 2008). This is due to the lack of opportunities for education, long periods of confinement, not 
enough outdoor activities, along with being separated from their parents, they are at a higher risk of further developing the aforementioned mental health issues (Hadfield, 2008).

Over the years, it has been documented that more and more children are being detained in immigration detention centers emigrating from Central America entering the US. In addition, the "Zero-tolerance" policy implemented by the Trump administration has impacted more than 2700 refugee children from El Salvador, Guatemala, Honduras, and Mexico in 2017 and 2018 who were split from their immediate family members (Chen, 2019). Specifically, children who were detained are held in detention facilities with deplorable conditions that violate their fundamental human rights. For instance, the rooms where claimants are kept in are tiny and mirror prison cells, and the attempt to maximize space has caused overcrowding, which not only violates both safety and fire regulations but is against basic human rights of asylum seekers (Teicher, 2018). The "Zero Tolerance" policy has been widely condemned by politicians, academics, various professionals, and the overall general public for detaining and holding children in detention centers with deplorable conditions (McDonnell \& Merton, 2019). As time passes, stricter policies will need to be introduced by both Canadian and the US governments to avoid placing immigrant detainees, especially children at higher risks of developing severe mental health issues due to the deplorable conditions of detention centers in both nations which will make sure it limits the possibilities of PTSD, depression, and anxiety.

\section{Inadequate Access to Health Care in Detention Centers}

A second central argument of this paper is that due to inadequate access to proper health care, the mental health of the detained asylum seekers is at risk of further deterioration. In order to advance this argument, the evidence is drawn from the social exclusion framework. According to the social exclusion theory, social isolation results from enforcing the basic elements to 
exclude asylum seekers by keeping them in detention centers actively. It is found that the social exclusion theory has dramatically influenced the Canadian and American policies with the establishment of immigration detention centers. This is a powerful and physical manifestation of exclusionary state practices that are designed to limit the mobility of asylum seekers (Tieicher, 2018).

There is a genuine fear that irregular arrivals of undesired bodies entering into Canada and the US would impose a risk to national security and the western society since there is a widely held common belief that many asylum seekers might bring with them backward ideologies which would be diametrically opposed to Western values (Mucati, 2018). As a result, both Canada and the US have adopted certain policies to deter a large number of refugees from crossing the borders and entering these countries. Therefore, these state-regulated policies have contributed to the construction of a controlled space, which is the immigration detention facilities (Mucati, 2018). As a result, these facilities play a pivotal role in the social exclusion, marginalization, and isolation of refugee families and children who are detained (Mucati, 2018). Building on the framework of social exclusion, it is easy to understand how detention centers using the elements of social exclusion are inflicting mental health issues such as PTSD and high levels of anxiety. The exclusion of asylum seekers from social and economic spaces in the city limits the mobility of asylum seekers' families and children and makes them isolated by feeling overly anxious (Martin, 2015). The immigration detention facilities in these two nations, especially the American facilities, restrict mobility and interaction between detainees. Children's separation from their families and parents often leads to depression, anxiety, PTSD, and add on to their variegated mental health issues when they are marginalized and isolated by being placed in detention facilities (Cleveland and Rousseau, 2012). Children are only able to reunite with the 
families on rare occasions solely if their status becomes legal after the due process, which can be extremely lengthy (Global Detention Project, 2017). In many cases, parents and families never see their children who end up in foster care homes or the hands of the caregivers. The children that do get to reunite with their families and parents eventually are severely traumatized in the detention facilities due to lengthy separations as well as segregation (Piwowarczyk, 2007). The emotional scars caused by separation in detention centers may take up to years to heal and can be seen as a systematic issue and not a one-off event that is exclusive to one child (Piwowarczyk, 2007).

Furthermore, it is essential to note that immigration detention centers are built on the premise of excluding asylum seekers from domestic citizens. Thus, these facilities are a channel to increase the distance between domestics and asylum seekers and to make sure these two types of people interact as little as possible.

\section{Implications Resulting from Limited Access to Health Care}

In addition, the literature review provides evidence that by using the ideology of social exclusion, there can be detrimental side effects on the mental health of asylum seekers. The access to adequate healthcare is essential for detainees with mental health issues in detention centers in both Canada and the US, yet the existing literature points out that medical treatment provided to detainees in both countries is often inadequate. The placement of these facilities in rural locations and housing asylum seekers in an isolated manner without adequate access to health care only further stimulates PTSD and increases the level of anxiety (Hadfield, 2008). The physical or geographical location of these facilities is socially marginalized to prevent asylum seekers from seeing their children or other members of the family or connecting from the general public of the host city (Martin, 2015). This is a violation of their UDHR Article 13, which 
promotes that everyone has the right to freedom of movement (UNHCR, 2018). This human right is indeed not enforced by these facilities as asylum seekers are not able to see their children very often or even engage much with other asylum seekers inside the facility (UNHCR, 2018).

Furthermore, one can argue that detention centers have taken this right away from the detainees by subjecting and confining them to detention centers and segregating them from their family members. The violation of their human rights can be further explained and supported by Anthony Richmond, who argues that social exclusion is not only about poverty or having access to similar resources rather, social exclusion extends beyond that - which is violating and taking away their human rights (Richmond, 2002). This mirrors the situation in these facilities since they actively deny the detainees' access to Article 13 of UDHR.

The presence of detention centers and access to healthcare for asylum seekers in these facilities in Canada and the US differ. For instance, there is one difference that stands out between Canada and the US, which is the number of detention facilities in these countries. While Canada only has three detention centers operating, the US, on the other hand, has more than two hundred facilities all across the different states. The detention sites in the US are mostly privately run that are used to hold undocumented migrants (Global Detention Project 2017). These private detention facilities fail to meet their obligations in providing adequate healthcare services because they are mainly interested in housing asylum seekers in order to make a profit and the US government has not been monitoring the living conditions of privately run detention facilities properly (Haberman, 2018). There have been cases where detainees diagnosed with severe trauma and anxiety are required to receive immediate medical attention, but with the limited medical resources available, detainees are unable to receive the necessary medical treatment. It has been reported that detainees with PTSD and high levels of anxiety are left untreated, which 
can further exacerbate their overall mental health leading to severe depression (Global Detention Project, 2017).

In Canada, immigration detention centers are heavily monitored and regulated to comply with the National Immigration Detention Framework, but there are general concerns raised despite regulations. As the US relies more on privately owned and operated detention centers with deplorable conditions, Canada has also resorted to the usage of provincial jails that have dramatically increased over the years. There is little information available to describe how these provincial detention facilities are regulated and monitored. However, concerns have been raised regarding the horrible treatment of delaines, including the lack of access to health-care services (Global Detention Project, 2018). These concerns have been refuted by CBSA, who claims that detainees in Canadian detention facilities do have access to more specialized health care services that can be utilized by anyone (Muscati, 2018).

However, the research indicates the contrary to this statement made by the CBSA, access to mental care has been described as very inadequate and therefore triggers new mental health issues affecting the overall mental health of detainees (Muscati, 2018). The literature review laid out a trend in both countries - both are interested in placing the asylum seekers far away from the main cities or citizens in order to hide them. As a result, this has caused both Canada and the US to purposely neglect the availability of health care for asylum seekers, which can be obtained whether the government runs the facilities through provincial jails, or it can be done through privately owned and operated sites.

Although primary medical care is provided in Canadian detention facilities, no other counseling or mental health support is provided, which plays a massive role in helping suicidal detainees from self-harm (Muscati, 2018). Instead of providing counseling and other medical 
support to suicidal detainees, they are placed under $24 / 7$ surveillance or taken to solitary confinement, and if all options fail, they are transformed into provincial jails (Muscati, 2018). As mentioned above, there is little information, if any, is available regarding the overall conditions of provincial jails, especially on the extent to which healthcare is provided. It is reported that during specialized medical care visits, all detainees are handcuffed and shackled. For instance, one detainee described his horrific treatment as being chained during dental surgery, and women suffered the most, being chained to their bed after just giving birth (Global Detention Project, 2018). Also, there have been countless reports describing the treatment of asylum seekers being handcuffed like criminals while enduring shame in public (Muscati, 2018). These experiences speak volumes of the kind of treatment asylum seekers are subjected to, which further contributes to their trauma, anxiety, and eventually developing high levels of depression (Global Detention Project, 2018).

The existing literature highlights that not only adults suffer due to the lack of access to health care services, but children also suffer, and the impact on the children is far worse because of their vulnerable age (Magalhaes, Carrasco, Gastaldo, 2009). Malina (2019) stresses that children due to their fragile mental state often have more medical needs when exposed to violence, torture, and trauma, along with being held in detention centers for a lengthy period. It is reported that in the US, during the fiscal year of 2014, CBP detained more than 68,631 unaccompanied minors and another 68,684 in family units by holding them in detention facilities (Malina 2019). Most of these children are already victims of war, violence, as well as torture and have pre-existing mental health conditions as a result of having been through the aforementioned traumatizing experiences. The facilities they are placed in lack the primary 
health care resources that can provide much needed and effective treatment to these children that are suffering from depression and anxiety (Linton, Griffin, and Shapiro, 2017).

This point is further supported by Malina (2019), who points out that there is no set process to ensure that unauthorized unaccompanied minors held in private detention centers receive the proper medical attention that would be in their best interest. She further states that the US is the only country in the world that has not signed the Convention focusing on the rights of children, making it even more challenging to monitor the treatment of children in these detention centers (Malina, 2019).

In addition, children in the US detention facilities that do receive medical treatment is without the consent of parents because parents usually are separated from their children. Multiple reports have highlighted that children were increasingly pressured to consenting to medical treatment and were medicated by the usage of psychotropic medication to control their behavior (Driver, 2018). This shows the abuse that children are subjected to, which violates their universal human rights put forward by the 1951 UN Convention, which Canada also signed on to (Malina, 2019). On the bright side, there have been advocacy groups calling upon the forced consent to end immediately and only administer psychotropic medication in emergency cases as defined by the state law.

However, in privately run detention facilities, these laws have been largely neglected, and there is no set way to regulate these privately run detention facilities that either provide no access to health care at all or provide deplorable medical services that negatively affects the overall health of children. Linton, Griffin, and Shapiro (2017) suggest that children with trauma, depression, anxiety, and severe mental health issues should receive proper counseling and medical attention in due time for them to get better; otherwise, as time progresses, the children 
will become further traumatized and develop severe health issues. Furthermore, comparing the treatment of children in the US to Canada is not different, because, under section 60 of IRPA, children should not be detained, but only as a last resort, while still considering the overall interest to ensure that they are protected against any harm caused in the detention facilities (Global Detention Project, 2017). However, Canada has failed to consider the best interest of undocumented children held in detention facilities violating the Convention on the Rights of Child. It is reported that children in Canadian detention centers suffer equally compared to the children in the US detention facilities in terms of poor access to health care services.

The literature above concludes that Canada and the US heavily rely on privately run immigration detention facilities that lack proper health resources to refugee detainees. A detainee with previous mental health conditions tends to suffer when not provided appropriate treatment, and it is further exacerbated for being held in these detention facilities for an extended period of time (Haberman, 2018). Advocacy groups that have called on to improve the conditions of the detention facilities have been ignored, or very little is done to address the overarching issue.

In short, this research indicates that detainees that face confinement, restrict regulation, and limited mobility was found with signs of further exacerbation of pre-existing stress conditions, causing an array of mental health issues such as depression, anxiety, and PTSD (Werthern et al., 2018). It is evident from the literature that those who were subjected to these deplorable conditions in detention centers had their basic human rights violated and were treated inhumanely. The state policies are designed to marginalize further, isolate, and socially exclude detainees from seeking legal status and becoming part of the wider society. 


\section{Resemblance to Force Confinement Imposing Family Separation}

In this section, the third central argument of this paper is advanced that the living environment for asylum seekers in detention centers mirrors the conditions of those in forced confinement and contributes to family separation. As mentioned earlier, the current literature highlights that the forced confinement of detainees leads to developing mental health issues, especially for people with a previous history of mental health problems. In Canadian detention facilities, asylum seekers (adults and children) are held in small detention facilities with restrictions and limited mobility (Muscati, 2018). They are under constant surveillance, and their daily routines are controlled by following strict schedules and rules with designated meals and bedtimes. They are not able to communicate with anyone unless authorized to do so, and the doors of their cells are not allowed to be closed, even at night time (Global Detention Project, 2018).

There have been reports that in Canadian facilities, many detainees have complained that their privacy was violated and experienced sleeping difficulties due to the constant light and noise from hallways, which is abusive, and these can trigger mental health issues. The movement in these facilities is controlled and undoubtedly limited. For instance, when moving within the facilities, adults and children are often subjected to body searches when leaving and entering the building. They may only move within the facilities when accompanied by guards (Cleveland and Rosseau, 2013).

Also, children are detained with their mothers in a separate wing from their fathers, and family visits are generally limited to short periods each day. Recreational activities and access outside is minimal for children, which further confines them to the walls of the holding centers (Cleveland and Rosseau, 2013). These factors have deprived children of a suitable environment 
where they could be accommodated; thus, it is severely detrimental to the long-term health of the children. Many of these children who are accompanying their parents in detention centers suffer the most because they cannot have their best interests considered by the adjudicator during a detention review hearing (Cleveland and Rousseau, 2012).

This is a clear violation of children's rights as guaranteed by the UN Convention on the Rights of the Child that clearly lays out what rights children must have in order to develop to their optimum potential. The Convention guarantees the same rights to children as those that are set for adults with some additional rights that take the various ages of a child's development into consideration (UNHCR, 2018).

It further emphasizes that the basic quality of life should be the right for all children and not something that is only enjoyed by some children. In light of this right guaranteed by the UN Convention, it is clear that the placement of children in detention centers is in clear violation of a child's right to the basic quality of life (UNHCR, 2018). Canada has continuously violated this international law by detaining children in immigration detention centers. Some studies highlight that detainee children have experienced psychiatric symptoms, depression, anxiety, and selfharm, which delays their overall growth and development (Silove, 2000).

In contrast, in the US, detainees are subject to even worse confinement compared to that in Canadian detention centers. Detainees are typically locked down for at least 22 hours a day, with limited access to recreation or contact with other human beings (Coffey et al., 2013). When in solitary confinement, an individual can be limited or denied complete access to phone calls, visits, books, or any personal items that can be used to help the person. This is further supported by research conducted by Coffey et al. (2013), which states that the environment of detention 
facilities can be characterized by total confinement and deprives the liberty and freedom(s) of the person(s).

In addition, the atmosphere in the US detention facilities has been described as very harsh for following a fixed routine without any freedom given to the asylum seeker(s) as the detention facilities are equipped with extensive surveillance, and monitoring measures, including high wire and razor, wired fences to prevent people from escaping (Coffey et al., 2013). There are reports which suggest that guards continuously watch detainees, and there have been times that incidents have occurred where unlawful physical force is used against the detainees. This has been made possible due to a lack of regulations for the guards who know that they can get away with this behavior since the detained asylum seekers are not in a position to complain. Similarly, the body and room searches are always conducted with force at the discretion of the guards at any given time (Coffey et al., 2013). In short, the literature review shows that in both Canada and the US, the detention centers place and restrict the mobility and freedoms of the detainees by keeping them in confined quarters with limited access to others leading to family separation.

Thus, this study finds that the conditions of forced confinement have driven family separation amongst detainees. This is another critical factor that is present in detention centers in Canada and the US. In the past, Canada has succeeded in reuniting families that have proven to be beneficial for society as a whole as it promotes positive reinforcement of refugee settlements in communities across Canada. This positive narrative about family reunification has been promoted since the 1970s when Canadian immigration policies went through rigorous changes to reunite families (Deshaw, 2006). Moreover, this practice has been very successful in the current day by allowing Canadian citizens and permanent residents to unite with their families. However, the current immigration policies are contrary to the treatment of migrants held in 
detention centers that have resulted in the separation of families. For instance, upon arrival, asylum seekers without proper documentation are immediately sent to immigration detention centers. Under international law, men, women, and especially children should not be arbitrarily detained. Canadian immigration policies do not allow children to be separated from their parents, yet children are separated from one parent, their father, and permitted to remain with their mother in the detention centers (Muscati, 2018).

In some cases, children whose parents are detained are handed to child protection services, which not only results in adverse outcomes for the children but also their parents (Muscati, 2018). In other cases, where children are separated from their parents, they end up within foster institutional care or adoptive homes that contribute to their pre-existing experience of war, violence, and persecution. Family separation further affects the overall well-being of children (Coffey et al., 2013). Most families that are released from the detention centers continue to have ongoing emotional distress, depression, and anxiety that they developed during their time in detention centers, especially the children (Coffey et al., 2013). The traumatizing fear of being separated that they experienced in their home countries is repeated and often becomes a reality when they are forced to remain in immigration detention centers (Coffey et al., 2013). In most of the cases, $45 \%$ of the parents underwent separation, in which either one or both parents were detained and separated from their family and children (Lustig et al., 2008). Despite the overwhelming evidence that detention centers enforcing family separation leads to long-term health outcomes, little attention is paid by the Canadian government to address these issues. (Lustig et, al, 2008). It can be concluded through this review that the Canadian government has failed to put an end to family separation by not amending its immigration policies on detention centers. The government continues to chant the mantra of introducing policies to improve the 
conditions and treatment of migrant detainees in the detention centers, all the while it is misleading the general public as well as the asylum seekers.

In contrast, family separation in the US is even worse when compared to that of detained families in Canada. According to the Global Detention Project (2017) report, in 2017, there were 323, 591 immigrant detainees held in detention centers, with 44,270 asylum seekers detainees. This number continues to increase every year. The Obama Administration introduced reform policies in 2009 to make changes to immigration detention facilities and reduce the number of people being detained; however, the number of detainees between 2009 and 2012 increased tremendously due to a large number of asylum seekers crossing the American border in search of safety (Global Detention Project, 2017).

In addition, the literature review indicates that the purpose behind privately run immigration detention facilities is to deal with a large number of immigrant detainees; within this process, families are forcefully separated and detained to deter a large number of unwanted migrants (Musalo and Lee, 2017). For instance, the zero-tolerance' immigration policy initiated by Trump administration led the forced removal of more than thousands of children from their parents (Teicher, 2018). The US Department of Health and Human Services reported that 10,773 unaccompanied minors were separated from parents and detained in immigration detention facilities that crossed the borders from Mexico (Teicher, 2018). Wood (2018) described the conditions in these detention centers as inhumane and cruel, which detainees, including children, were being subjected to as part of the Zero Tolerance Policy.

Clinically, evidence from studies shows that unaccompanied minors entering the US who are detained are at a higher risk of developing PTSD, anxiety disorder, depression, aggression, psychosomatic complaints complains, and suicidal acts (Teicher, 2018). There were also reports 
that children at the detention centers were also prohibited from touching or hugging each other, including their siblings (Teicher, 2018). Opposing politicians have highly criticized the separation of children from their parents at the US border and being detained in detention facilities; however, their attempts have still not yielded any action from the governing bodies (Teicher, 2018).

Furthermore, it is evident from the above research that both Canada and the US have contributed to the family separation of asylum seekers, which in fact is a direct infringement of the Rights of Refugees as guaranteed by Article 28 of the 1951 Refugee Convention (UNHCR), which outlines that the unity of the family which is considered by the Convention to be the natural and fundamental group unit of society, is an essential right of an asylum seeker or refugee (UNHCR, 2018). The UNHCR further recommends that Governments should emphasize and proactively take action that is necessary for the protection of the refugee's family. Yet both Canada and the US have failed in offering this protection to asylum seekers and refugees by forcing them into confinement in detention centers and separating the children from their fathers.

Comparing and contrasting the issues of limited healthcare, forced confinement causing family separation in Canada and the US shows strong similarities. Both countries have forcefully detained immigrants and have subjected them to deplorable, inhumane conditions in detention facilities that violate their basic fundamental human rights. As a result of these factors, immigrant detainees in both countries have developed anxiety, depression, PTSD, and related mental health issues that will continue to last long after their release from detention centers. 


\section{POLICY RECOMMENDATIONS}

\section{Alternative to Detentions Programs}

This part of the paper will focus on the policy recommendations based on the literature review to demonstrate how Canadian and the US administrations can use their resources to come up with better alternatives to detention centers and also improve the overall conditions of the existing detention centers. The immigration detention framework has drawn strong criticism and commendations from the UN, non-governmental or profit organizations, human rights advocates, academics, and various professionals (International Organization for Migration, 2018). There is wide-ranging evidence suggesting that countries around the world should adopt more viable alternative approaches to immigration detention policies. Alternatives to Detention (ATD) are considered as more effective and humane methods to administer the arrival of unauthorized immigrants or asylum seekers while protecting border security (Bosworth, 2018).

ATD will not only effectively manage migration, but also respect international law(s) and standards to honor and protect the fundamental human rights of asylum seekers and refugee claimants (Sampson and Mitchell 2013). The separation of families, and especially the separation of children from their parents in the detention centers, further exacerbates their overall wellbeing and mental health, many of whom have already been suffering trauma, depression, and anxiety (Mitchel, 2015). There is a body of literature that recommends that the adaptation of ATD options is very effective in terms of addressing the well-being of undocumented migrants. The literature that has been reviewed argues that ATD options are defended as more humane, dignified, and respectful treatments for asylum seekers with families and children, when entering the country (Bosworth, 2018). 
ATDs require a high rate of compliances with respect to immigration proceedings by providing detainees with adequate health support, case management, and legal services to help them understand their rights and duties (Sampson and Mitchell 2013). The appropriate help and resources will support refugees with respect to making a successful refugee claim(s) without facing difficulties or barriers (National Immigrant Justice Center, 2019). The ATD option is not a single measure to be implemented; instead, it's an umbrella of different programs offered as an alternative to detention centers, which would cater to the needs and wants of the asylum seekers in a meaningful manner (International Detention Coalition, 2020). There are several ATD programs options that can be considered by the two nations so that they are not violating the fundamental human rights of asylum seekers.

There is robust evidence to support the implementation of ATD Community Based Programs, which will allow individuals to live in the community by receiving support from family or an organization that will accommodate their needs. This will ensure that compliance with the program requirements is met by asylum seekers (Government of Canada, 2019). This approach has been in existence in both countries for decades and is seen as more beneficial and safer to immigration detention centers (National Immigrant Justice Center, 2019). The support for the ATD community-based programs has been growing around the world. For instance, the National Immigrant Justice Center (NIJC), located in Chicago, US, focuses on how the US should treat asylum seekers, refugee claimants, undocumented migrants seeking safety and protection in the country. The documented research has suggested that there is a strong possibility of achieving success in implementing community-based programs under the umbrella of ATDs. 


\section{ATD Community Based Programs}

This paper has narrowed down a few ATD Community based programs examples that are currently in practice and have proven to be effective.

\section{Sweden}

When researching community-based programs that have proven to be effective, the example of Sweden came to the forefront of the research. Although Sweden does have immigration detention centers, it is much limited in scope when compared to Canada and the US (National Immigrant Justice Center, 2019). In Sweden, the unauthorized migrants are only detained for less than two weeks, in which they go through a process of verification with respect to their identification. Instead of relying on immigration detention centers, the program relies more on community centers to welcome the unauthorized migrants to quickly integrate them into the country (National Immigrant Justice Center, 2019).

The first process of the program is the initial screening and assessment, which is completed by registering with the Sweden Migration Agency to assess their overall condition in order to provide asylum seekers with help such as health, psychological and economic (National Immigrant Justice Center, 2019). The second step is Case Management, where a photo identification is provided to asylum seekers that are used to access various services and resources available in different community centers (National Immigrant Justice Center, 2019). A caseworker is also appointed to explain the legal system and their rights and helping them to navigate their way to making a refugee claim. The third step is community placement, where the first few weeks are spent at the community center, and then the transfer is made by providing housing for families and single asylum seekers. This is another positive factor in keeping families united and not forcefully separating them (National Immigrant Justice Center, 2019). As 
the above literature has documented that the forceful separation of families and children from their parents in Canada and especially in the US, where this occurs mostly, has a drastic impact on the mental health of asylum seekers. In contrast, Sweden takes a more humane and friendly approach to keep families together by providing them with a house and granting them full freedom of movements in the community (Sampson and Mitchell 2013). The final step is human needs, in which asylum seekers in Sweden are given access to medical care, including gynecological care, parental care, and free emergency medical or dental care. In addition, living in the community, asylum seekers regularly meet with their caseworker to receive legal assistance and other services to help them in their case (National Immigrant Justice Center, 2019).

\section{The Toronto Bail Program}

The Canadian state has faced a lot of criticism for resorting to immigration detention policy to address the large influx of detainees arriving from different parts of the world. As the above literature has highlighted that Canada has held the reputation of a humanitarian and compassionate country for aiding asylum seekers and refugee claimants by protecting their fundamental human rights (Saberpor, 2016). However, the reality is to the contrary. The literature sheds light on how different non-profit organizations, human rights, and advocacy groups have called on the Canadian state to put an end to immigration detention centers and adopt more humane approaches when dealing with immigration detainees. In 2018 the Canadian government collaborated and entered into a partnership with three different non-governmental organizations to provide supervision and case management to asylum seekers to help navigate their way to successfully making a claim in Canada (Government of Canada, 2018).

The three non-governmental organizations include the Salvation Army, the John Howard Society of Canada, and the Toronto Bail Program known for their well-supportive roles in 
providing help and resources to many refugees and asylum seekers (National Immigrant Justice Center, 2019). The model expands on the Toronto Bail Program by releasing the asylum seekers, refugee claimants, and individuals without legal status into the community with conditions that must be followed (National Immigrant Justice Center, 2019). The programs provide assistance and robust case management support to individuals during their case process. This has turned out to be more effective with a 90 percent compliance from participants (National Immigrant Justice Center, 2019).

Moreover, this partnership is one of the leading examples implemented by the CBSA with the intention of reducing the number of individuals held in detention centers. Prior to releasing an individual into the community as part of the partnership with different organizations, further assessment is done to ensure the person is suitable for release into the community keeping the public safety and national security at the forefront (National Immigrant Justice Center, 2019). The partnership with the different organizations is only one aspect of the program. For instance, under the ATD community programs, an individual can also be released into the care of family members or a third party that meets the requirements of the ATD programs. As part of the ATD program, the CBSA has partnered with Community Case Management and Supervision (CCMS) with the aim of providing health and mental health support, referrals to employment and housing support, help for families and children, and overall to help ensure that individuals are able to navigate their way while their case is going through due process (CBSA, 2019).

In addition, the CBSA has Electronic Supervision, Voice Reporting (VR), and Electronic Monitoring (EM) that are used for the individual to communicate with the CBSA to comply with the requirements of the ATD. Thus, these programs have been very beneficial with respect to 
public safety and national security, and the overall compliance of the program (Government of Canada, 2019).

The aforementioned assessment concludes that Canada should continue to implement more community-based programs as an alternative to detention centers, which respects human rights of immigrant detainees, are cost-effective, and will allow the state to exercise its sovereignty in protecting border control policy. In addition, this will also protect asylum seekers from their rights being violated (Wachuku, 2019). As this program has been very successful in the city of Toronto, the adoption of this program is highly recommended for all the provinces across Canada.

\section{Marie Joseph House}

The US is known mostly for resorting to the immigration detention centers in order to control the large immigration population and maintain border control policy. This report highlights that many organizations have resorted to community-based programs to help undocumented migrants, and a very successful example of this is found in the Marie Joseph House operated by the Interfaith Community for Detained Immigrants (ICDI) in Chicago (National Immigrant Justice Center, 2019). This is one of the many programs as part of the ATDs that is serving asylum seekers, refugee claimants, and undocumented migrants to make their experiences beneficial while making a positive impact on their health and overall quality of life (Mousin, 2016). The program provides basic shelter, food, and robust case management to immigrant detainees that are released from detention in order to help them transition into their community and navigate their way in the process of their pending legal process (National Immigrant Justice Center, 2019).

This community-based program also offers resources and tools such as health, education, and legal advice to help undocumented migrants, the positive impact of which has also been 
observed by both the community and the government. It has been documented that released asylum seekers previously held in detention centers found solace when they were placed in a house instead of a detention facility (National Immigrant Justice Center, 2019). For the first couple of months, released detainees spent their time recovering from emotional stress they endured at the detention centers. The Marie Joseph House played a pivotal role in the healing process of asylum seekers so they would be able to move forward readily integrating into the community (Mousin, 2016).

This program has been very successful and overall cost-effective in dealing with immigrant detainees. This example has generated a lot of awareness and interest in the government and other stakeholders. For instance, the Trump Administration and Congress in the US have been searching for measures to tackle the substantial number of migrants coming from Northern Triangle (Guatemala, Honduras, and El Salvador) in the hopes of applying for refugee status (Congressional Research Service, 2019). In this context, the Department of Homeland Security (DHS) and congress are relying more on ATD as a possible solution to address the issue of the growing immigrant population. This program has both proponents and critics that have argued in favor of and against ATDs (Congressional Research Service, 2019). For instance, proponents, have pointed out the lower daily costs compared to high detention cost for detainees, and also the high compliance rates of ATDs participants of the immigrant detainees. In addition, ATDs community programs are described as more humane that protect the rights of immigrant detainees from being violated or being subjected to inhumane and cruel treatment (Congressional Research Service, 2019).

The above examples provide ample evidence that the ATD community-based approach can provide local administration (city or statewide), the ability to administer how many asylum 
seekers are successfully integrating into the economy and society. In contrast, for asylum seekers, these adaptations of ATD Community Based Programs by both Canada and the US will allow the asylum seekers to ensure that they have a sense of belonging since they will be placed in a community rather than being isolated in detention centers. In addition, as these programs become more prevalent in Canada and the US, scholars can investigate to see what potential challenges are being posed towards the asylum seekers by these alternative programs and focus on how they can improve. 


\section{CONCLUSION}

In conclusion, this paper has demonstrated that Canada and the US have tailored their own style of dealing with asylum seekers through the use of detention centers. This paper has shed light on the immigration policies and the treatment of asylum seekers that are detained in Canada and the US by looking at its similarities and differences. In addition, this paper evaluates the growing literature review of detention centers and the mental health implications on asylum seekers by looking at policy documents, scholarly contributions, and the popular press.

Furthermore, this paper utilized the framework of social exclusion to understand how much harm is being placed upon asylum seekers. In this context, this paper has charted out how these two nations have primarily used the logic of the social exclusion framework to house asylum seekers into these facilities intentionally. Moreover, it assessed how these facilities are inflicting mental health implications on asylum seekers by keeping them in confined spaces. In this context, this paper makes the overarching claim that detention centers not only impose mental health issues such as post-traumatic stress disorder and contribute to high levels of anxiety-causing depression as well as mental breakdown due to inadequate access to proper health care available.

In addition, it has been argued in this paper that the living environment in these detention centers is similar to that which is seen in prisons contributing to family separation and forcing mental health implications on the asylum seekers. Therefore, this paper provides the alternatives that these two nations can benefit from by obtaining and placing ATD's as an effective method in dealing with the influx of asylum seekers. This alternative policy recommendation would serve as a more suitable and sustainable way to accommodate the needs of asylum seekers. Adopting these recommendations would bring about positive change in including the asylum seekers into the fabric of Canadian and American society. 


\section{REFERENCES}

Alamyar 2, N. (2016). Detention in Canada of asylum claimants for identity determination: A critical review of the literature pertaining to Canada's immigration detention centers. Retrieved from https://digital.library.ryerson.ca/islandora/object/RULA:4857

AILA - Due Process Denied: Central Americans Seeking Asylum and Legal Protection in the United States. (n.d.). Retrieved from https://www.aila.org/infonet/report-due-process-denied.

Americanimmigrationcouncil.org. (2019). [online] Available at:

https://www.americanimmigrationcouncil.org/sites/default/files/research/an overview of us ref ugee law and policy.pdf [Accessed 9 Jan. 2020].

Berlinger, J. (2019). Canada resettled more refugees than US in 2018, UN says. Retrieved 13 January 2020, from https://www.cnn.com/2019/06/19/americas/canada-us-refugee-resettlement$\underline{\text { hnk-intl/index.html }}$

Bosworth, M. (2018). Alternatives to Immigration Detention: A Literature Review. Retrieved 5 January 2020, from https://papers.ssrn.com/sol3/papers.cfm?abstract_id $=3299532$

Canada Border Services Agency. (2018, July 24). Alternatives to Detention Program. Retrieved from https://www.canada.ca/en/border-services-agency/news/2018/07/alternatives-to-detentionprogram.html.

Chen, M. (2019). There Are Still Migrant Children Separated From Their Families. Retrieved 4 January 2020, from https://www.thenation.com/article/archive/family-separation-border-centralamerican-immigration-crisis/

Cleveland, J., Rousseau, C., \& Kronick, R. (2012). The harmful effects of detention and family separation on asylum seekers' mental health in the context of Bill C-31. Brief submitted to the House of Commons Standing Committee on Citizenship and Immigration concerning Bill C-31, the Protecting Canada's Immigration System Act. Retrieved from

http://www.csssdelamontagne.qc.ca/ fileadmin/csss_dlm/Publications/brief_c31_final.pdf

Cleveland, J., Rousseau, C. (2013). Psychiatric symptoms associated with brief detention of adult asylum seekers in Canada. The Canadian Journal of Psychiatry, 58, 409-416.

Coffey GJ, Kaplan I, Sampson RC, Tucci MM. The meaning and mental health consequences of long-term immigration detention for people seeking asylum. Soc Sci Med. 2010; 70(12):20702079

Congressional Research Service (2019). Immigration: Alternatives to Detention (ATD) Programs Retrieved 17 January 2020, from https://crsreports.congress.gov/product/pdf/R/R45804 
DeShaw, R. (2006). THE HISTORY OF FAMILY REUNIFICATION IN CANADA AND CURRENT POLICY. Canadian Issues, 9-14. Retrieved from

http://myaccess.library.utoronto.ca/login?url=https://search.proquest.com/docview/208681485?a ccountid=14771

Driver, A. (2018, October 1). 13,000 migrant children in detention: America's horrifying reality. Retrieved from https://www.cnn.com/2018/10/01/opinions/13000-migrant-children-horrifyingreality-driver/index.html.

Global Detention Project 2017, countries - Global Detention Project: Mapping immigration detention around the world. Retrieved

https://www.globaldetentionproject.org/countries/americas/canada.

Government of Canada, Canada Border Services Agency. (2019, January 17). Alternatives to Detention Program Executive Summary. Retrieved from https://www.cbsa-asfc.gc.ca/agencyagence/reports-rapports/pia-efvp/atip-aiprp/atd-srd-eng.html.

Hadfield, K., Ostrowski, A., \& Ungar, M. (2017). What can we expect of the mental health and well-being of Syrian refugee children and adolescents in Canada? Canadian Psychology/Psychologie Canadienne, 58(2), 194-205. doi: 10.1037/cap0000102

Haberman, C. (2018, October 1). For Private Prisons, Detaining Immigrants Is Big Business. Retrieved from https://www.nytimes.com/2018/10/01/us/prisons-immigration-detention.html.

Idil Atak, Graham Hudson \& Delphine Nakache (2017). "Making Canada's Refugee System Faster and Fairer': Reviewing the Stated Goals and Unintended Consequences of the 2012 Reform", Canadian Association for Refugee and Forced Migration Studies (CARFMS) Working Paper Series 2017/3.

Julie M. Linton, Marsha Griffin, Alan J. Shapiro, COUNCIL ON COMMUNITY PEDIATRICS May 2017, 139 (5) e20170483; DOI: 10.1542/peds.2017-0483

Keller, A., Jocelyne, A., Granski, M., \& Rosenfeld, B. (2017). Pre-migration trauma exposure and mental health functioning among Central American migrants arriving at the US border. Plos One, 12(1). doi:10.1371/ journal.pone.0168692

Lacroix, M. 2004. "Canadian Refugee Policy and the Social Construction of the Refugee Claimant Subjectivity: Understanding Refugeeness.' Journal of Refugee Studies 17(2):147-66.

Lind, D. (2019, June 25). The horrifying conditions facing kids in border detention, explained. Retrieved from https://www.vox.com/policy-and-politics/2019/6/25/18715725/children-borderdetention-kids-cages-immigration

Lustig, S.L., Kureshi, S., Delucchi, K.L. et al. J Immigrant Minority Health (2008) 10:7. https://doi.org/10.1007/s10903-007-9056-8 
Levitas, Ruth \& Pantazis, Christina \& Fahmy, Eldin \& Gordon, David \& Lloyd, Eva \& Patsios, Demi. (2007). The Multi-Dimensional Analysis of Social Exclusion.

Martin, L. (2015). Noncitizen Detention: Spatial Strategies of Migrant Precarity in US Immigration and Border Control. Annales de géographie, 702-703(2), 231-247. doi:10.3917/ag.702.0231.

Magalhaes, L., Carrasco, C., \& Gastaldo, D. (2009, August 06). Undocumented Migrants in Canada: A Scope Literature Review on Health, Access to Services, and Working Conditions. Retrieved from https://link.springer.com/article/10.1007/s10903-009-9280-5

Malina, G. (2019, July 1). How Should Unaccompanied Minors in Immigration Detention Be Protected from Coercive Medical Practices? Retrieved from https://journalofethics.amaassn.org/article/how-should-unaccompanied-minors-immigration-detention-be-protectedcoercive-medical-practices/2019-07.

McDonnell, T., \& Merton, V. (2019). Enter at Your Own Risk: Criminalizing Asylum-Seekers. Retrieved 1 January 2020, from https://papers.ssrn.com/sol3/papers.cfm?abstract_id=3502556

Molnar, Petra. "Immigration Detention in Canada". The Canadian Encyclopedia, 07 September 2017, Historica Canada. https:/www.thecanadianencyclopedia.ca/en/article/immigrationdetention. Accessed 27 November 2018.

Mousin, Craig B. (2016) "You Were Told to Love the Immigrant, But What if the Story Never Happened? Hospitality and United States Immigration Law," Vincentian Heritage Journal: Vol. 33: Iss. 1, Article 8. Available at SSRN: https://ssrn.com/abstract=2784951

Muscati, S. (2018). Rights Violations Associated with Canada's Treatment of Vulnerable Persons in Immigration Detention. 1-288. Retrieved from https://ihrp.law.utoronto.ca/utfl file/count/media/Canada UPR Final.pdf.

Musalo, Karen, and Eunice Lee. 2017. "Seeking a Rational Approach to a Regional Refugee Crisis: Lessons from the Summer 2014 'Surge' of Central American Women and Children at the US-Mexico Border." Journal on Migration and Human Security 5(1): 137-79. https://doi.org/10.14240/jmhs.v5i1.78.

National Immigrant Justice Center. (2019). Report $\mid$ A Better Way: Community-Based Programming as an Alternative to Immigrant Incarceration. [online] Available at: https://www.immigrantjustice.org/research-items/report-better-way-community-basedprogramming-alternative-immigrant-incarceration [Accessed 5 Jan. 2020].

Piwowarczyk, L. (2007) Asylum seekers seeking mental health services in the United States. Journal of Nervous and Mental Disease, 195(9), 715-722.

Quigley, C. (2013, November 01). An Argument against Immigration Detention in Canada. Retrieved from https://tspace.library.utoronto.ca/handle/1807/43307 
Refugee Statistics | USA for UNHCR. (2018). Retrieved 11 January 2020, from https://www.unrefugees.org/refugee-facts/statistics /

Richmond, A.H. (2002). Social Exclusion: Belonging and Not Belonging in the World System. Refuge: Canada's Journal on Refugees, 21(1), 40-48. Retrieved from https://refuge.journals.yorku.ca/index.php/refuge/article/view/21282

Saberpor, T. (2016, January). Refugee and Asylum Seekers in Canada: Barriers to Health Care Services. Retrieved from https://gjis.journals.yorku.ca/index.php/gjis/article/view/40238/36415

Sampson, R., \& Mitchell, G. (2013). Global Trends in Immigration Detention and Alternatives to Detention: Practical, Political and Symbolic Rationales. Journal on Migration and Human Security, 1(3), 97-121. https://doi.org/10.1177/233150241300100302

Silove, D. (2000, August 2). Policies of Deterrence and the Mental Health of Asylum Seekers. Retrieved from https://jamanetwork.com/journals/jama/article-abstract/192952.

Teicher, M.H. (2018). Childhood trauma and the enduring consequences of forcibly separating children from parents at the United States border. BMC Med 16, 146 (2018) doi:10.1186/s12916018-1147

Taylor, J. (2004), 'Refugees and Social Exclusion: What the Literature Says', Migration Action, Vol. 26(2), pp. 16-31.

UNHCR, (2015). Women on the Run: First-hand Accounts of Refugees Fleeing El Salvador, Guatemala, Honduras, and Mexico, United Nations High Commissioner for Refugees 26 October 2015, available at: httpss://www.refworld.org/docid/563017e2a4.html

UNHCR (2012). N High Commissioner for Refugees (UNHCR), Guidelines on the Applicable Criteria and Standards relating to the Detention of Asylum-Seekers and Alternatives to Detention, 2012, available at: https://www.refworld.org/docid/503489533b8.html

United Nations. (2018). Convention and Protocol Relating to the Status of Refugees. Retrieved from https://www.unhcr.org/3b66c2aa10

U.S. Immigration and Customs Enforcement (2019), Department of Homeland Security: U.S. Immigration and Customs Enforcement: Budget Overview, pp. ICE - O\&S - 16

U.S. Immigration and Customs Enforcement (2018), Fiscal Year 2018 ICE Enforcement and Removal Operation Report

Usa.gov. (2019). Deportation | USAGov. [online] Available at: https://www.usa.gov/deportation [Accessed 06 Jan. 2020]. 
Von Werthern, Martha, Katy Robjant, Zoe Chui, Rachel Schon, Livia Ottisova, Claire Mason and Cornelius Katona (2018) "The Impact of Immigration Detention on Mental Health: A Systematic Review”, BMC Psychiatry, 18(382): 1-19.

Wachuku, V. C. (2019, April). Promoting and Challenging Immigration Detention in Canada: Understanding the Role of Advocacy Coalition Groups in Canada's Immigration Detention Policy Subsystem. Retrieved from https://www.ryerson.ca/content/dam/rcis/documents/V C Wachuku (2019) Promoting and Ch allenging Immigration Detention in Canada.pdf.

Wasem, R. (2010). U.S. Immigration Policy on Haitian Migrants. Retrieved 11 January 2020, fromhttps://www.researchgate.net/publication/235189151_US_Immigration_Policy_on_Haitian_ Migrants

Welch-Mitchell, Nicole, \& Charlotte Wheeler, (2015), The Mental Health of Refugee Children in Published online: The International Journal of Holistic Early Learning and Development, September 10, 2015 Edition period: Volume 2, 2015.

https://ijheld.lakeheadu.ca/article/download/1381/704

Wood LCN. Impact of punitive immigration policies, parent-child separation and child detention on the mental health and development of children. BMJ Pediatric Open. 2018;2(1):e000338. doi:10.1136/bmjpo-2018-000338 